\title{
The laterally closed tunnel for the treatment of mandibular gingival recession in thin biotype patients: case report
}

\author{
Hyun-Joo Kim ${ }^{1,2}$, Eun-Young Kwon ${ }^{3}$, Ju-Youn Lee ${ }^{1,2}$, Ji-Young Joo ${ }^{1,2 *}$ \\ ${ }^{1}$ Department of Periodontology, Dental and Life Science Institute, School of Dentistry, Pusan National University, Yangsan, \\ Republic of Korea \\ ${ }^{2}$ Department of Periodontology and Dental Research Institute, Pusan National University Dental Hospital, Yangsan, Republic \\ of Korea \\ ${ }^{3}$ Dental Clinic Center, Pusan National University Hospital, Busan, Republic of Korea
}

In this case report, gingival recession of the mandibular anterior teeth was treated with a laterally closed tunnel technique. Two patients had altered the inclination of mandibular anterior tooth during past orthodontic treatment and had periodontal thin biotype. The recipient site was formed by tunneling method, and the connective tissue graft obtained from the palatal side was placed in the tunnel, and the margins of flap were gathered at the center of the root and sutured. Despite the thin periodontal biotype, the root coverage was successfully obtained, keratinized gingiva was increased, and aesthetics were achieved by harmonizing with surrounding tissues in terms of shape and color. (J Dent Rehabil Appl Sci 2019;35(4):253-9)

Key words: gingiva surgery; gingival recession; esthetics; treatment outcome; surgical flaps

\begin{abstract}
서론
치은 퇴축은 치아의 백악법랑경계를 넘어 치은 변연이 이동하는 것으로, ${ }^{1}$ 하나 이상의 치은 퇴축을 보이는 환 자는 전체 인구의 $30-100 \%$ 에 이르며 연령의 증가와 함 께 유병률과 심도가 증가하는 것으로 알려져 있다. ${ }^{2}$ 치은 퇴축의 발생 메커니즘에 대해서는 아직 정확하게 밝혀진 바가 없으나, 이는 대개의 경우 치조골의 열개 발생이 선 행될 때 진행된다. ${ }^{3}$ 이와 관련되는 원인으로 악궁에서 치 아의 위치, 치은의 두께, 과하거나 부적절한 칫솔질 방법, 교정 치료, 소대 부착, 치은 염증 등을 들 수 있다. ${ }^{4}$

교정 치료와 치은 퇴축의 상관관계는 여러 연구들에 서 고찰되었으며, 치료 과정 중 하악 전치의 경사도를 조

\footnotetext{
*Correspondence to: Ji-Young Joo

Assistant Professor, Department of Periodontology, Dental and Life Science Institute, School of Dentistry, Pusan National University, 20 Geumo-ro, Mulgeum-eup, Yangsan, 50612, Republic of Korea

Tel: +82-55-360-5103, Fax: +82-55-360-5194, E-mail: joojy@pusan.ac.kr, Received: September 23, 2019/Last Revision: October 28, 2019/Accepted:
} November 13, 2019
\end{abstract}

절할 경우 치근이 치조골에 가깝게 위치함에 따라 치조 골 열개 및 치은 퇴축이 유발될 수 있다고 하였다. ${ }^{5}$ 그러 나 다수의 연구가 교정 치료 완료 후 변화된 하악 전치의 치축과 관련하여 치은 변연의 위치를 장기 관찰해보았을 때, 하악 전치 경사도의 변화와 치은 퇴축은 그 상관관계 가 낮다고 보고하였다. ${ }^{6}$ 이와 함께 고려해보아야 할 중요 한 요소로 치주 조직의 생체형을 들 수 있는데 이는 자극 에 대한 치은 퇴축의 발생 및 진행과 밀접한 관계가 있다. 치주 조직 생체형은 임상에서 간단한 방법으로 구분이 가능하며 치은 열구 내로 치주탐침자를 위치시켜 치은을 통해 비춰 보이면 얇은 형, 그렇지 않으면 두꺼운 형으로 나눌 수 있다. 전치부 변연 치은이 두껍거나 각화 치은의 폭이 넓을 경우에는 하악 전치의 경사도를 변화시키더라

Copyright@ 2019 The Korean Academy of Stomatognathic Function and Occlusion. (c) It is identical to Creative Commons Non-Commercial License. 
도 이후 발생 할 수 있는 치은 퇴축에 대해 저항성을 가지 는 것으로 알려져 있다. ${ }^{8}$ 하악 전치의 경사도를 변화시키 면 변연 치은에 장력을 가하게 되고 치은이 얇은 경우 이 는 치은 퇴축으로 연결될 가능성이 높다. 교정 치료 이후 치은 퇴축을 유발 할 가능성이 높은 요소로 치료 시작 전 치은 퇴축의 존재, 각화 치은의 폭, 치은 염증의 존재 및 치은의 생체형 등이 제시된 바 있다. ${ }^{9}$ 따라서 치주 조직의 생체형이 얇은 형인 환자에서 하악 전치의 경사도를 변 화시킬 경우 치은 퇴축이 발생할 가능성이 높을 것으로 예상 할 수 있다.

치은 퇴축은 보통 치은치조점막수술을 통해 해결되며, 이에는 유리치은이식술, 상피하결합조직이식술, 조직재 생유도술 등이 포함된다. 치근 피개에 관한 체계적 고찰 에 따르면, 치근 피개와 각화 치은의 증가 면에서 상피하 결합조직이식술이 가장 효과적인 것으로 보고 되었다. ${ }^{10}$ 하악 전치에서 특히 치은이 얇은 경우 상피하결합조직이 식술을 위한 수여부의 형성에 있어 판막의 찢김에 특히 주의해야 할 필요가 있다. 이에 Sculean와 Allen ${ }^{11}$ 은 깊게 형성된 하악 전치 치근 노출에 대해서 변형된 터널링법으 로 laterally closed tunnel법(LCT)을 소개하였는데, 이 술 식은 이식편을 터널 내에 위치 시킨 후 기존 터널링 법과 같이 판막을 치관방향으로 당겨 봉합하는 대신 치아의 중심에서 판막 변연을 모아 봉합한다.

이에 본 증례 보고에서는 과거 교정 치료를 통해 하악 전치의 경사도를 개선하였던 환자들 중 치주 생체형이
얇아 치은 퇴축이 발생한 경우에서 LCT법을 이용하여 성공적으로 치근 피개를 달성한 증례를 보고하고자 한다.

\section{증례보고}

\section{증례 1}

27세 여성으로 하악 전치 치은 퇴축을 주소로 본원 치 주과에 내원하였다. 임상 검사 상 \#31 순 측에 폭 $4 \mathrm{~mm}$, 길이 $3 \mathrm{~mm}$ 의 열개형 치은 퇴축과 함께 근단 경계 부에 약 $1 \mathrm{~mm}$ 정도의 각화 치은이 관찰되었다. 치간 유두의 퇴축은 없었으며, 치근단 방사선 사진 상에서도 인접 면 의 치조골 소실은 관찰되지 않아 Miller 1급의 치은 퇴축 으로 진단하였다(Fig. 1A, 1B). 치주 낭 깊이는 전반적으 로 2 - $3 \mathrm{~mm}$ 로 정상이었으나, \#31의 순 측으로 치은 발 적 및 부종, 탐침 시 출혈, 치태 침착이 관찰되었다. 더불 어 하순의 소대가 상방에 부착하여 치은을 아래로 당기 는 힘을 작용하고 있었다. 치주탐침자를 치은열구내에 넣었을 때 치은을 통해 치주탐침자가 비춰 보여 얇은 생 체형으로 진단하였다.

구강위생관리의 어려움으로 인해 발생한 국소적 치은 염으로 진단하고 해당 부위의 치석제거술을 시행한 후 구강위생교육을 시행하였다. 2주후 재 평가 하여 상기 증 상의 개선 및 구강위생관리가 양호한 수준으로 이루어지 고 있는 것을 확인하였으며 이에 치근피개술을 계획하였다.

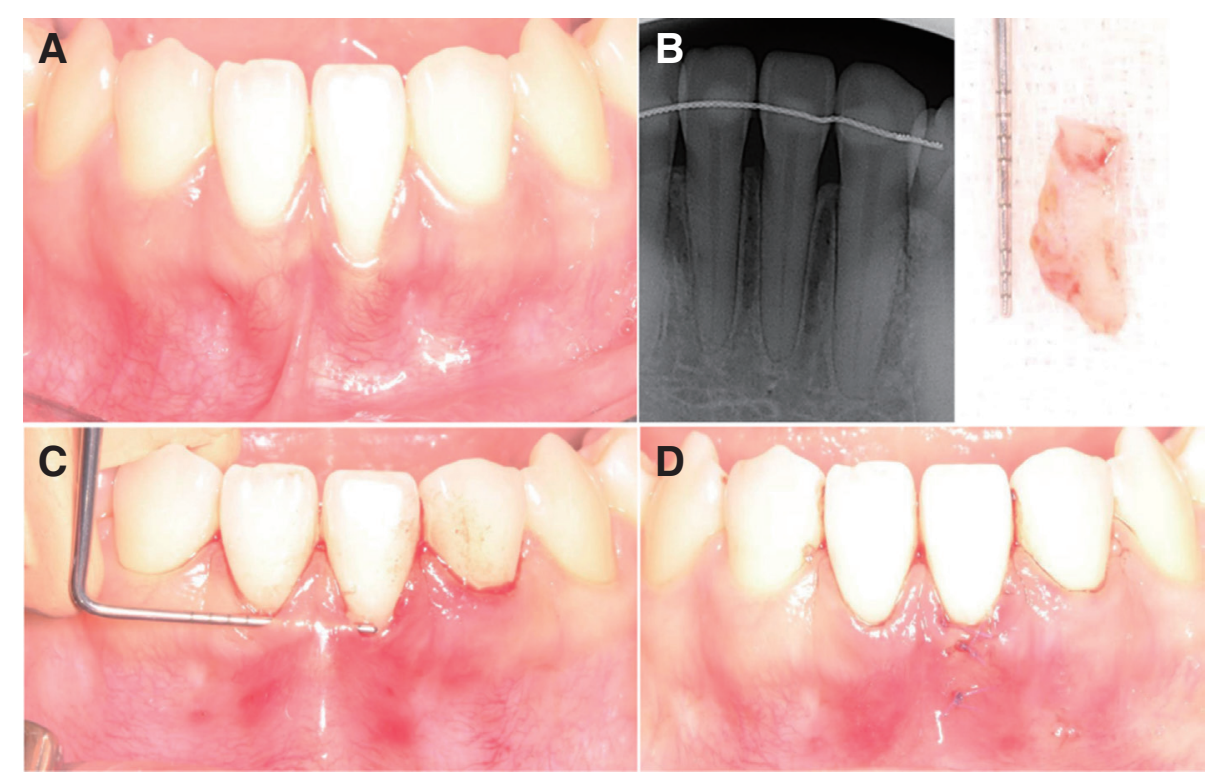

Fig. 1. Clinical photographic and radiographic view of case 1. (A) Intraoral photograph of \#31 at pre-operation, (B) Periapical radiograph, (C) Preparation of recipient site (tunneling), (D) Subepithelial connective tissue graft obtained from palatal, (E) Graft was positioned in the tunnel and sutured. 
해당 부위에 침윤 마취를 시행한 후 노출된 치근 면 을 활택 하였다. 미세 수술도(Mini-Blades, Ruttgers, Solingen, Germany)를 사용하여 해당 치아에 열구 내 절 개를 시행한 후 터널링을 위해 고안된 키트를 사용하여 (Modul plastic esthetic surgery set, Stoma, EmmingenLiptingen, Germany) 터널을 형성하였다. 이 때 터널은 치근단 방향으로 치은치조점막 경계를 넘어서 까지 형성 하였으며 근 원심 측으로 인접 치간유두부의 아래를 박 리하였다(Fig. 1C). 내면으로 연결된 근육과 교원 섬유는 미세 수술도와 큐렛을 이용하여 박리하였으며, 순 소대 의 부착을 확실하게 끊어주었다. 터널의 근 원심측 경계 가 장력없이 중앙에서 만나 노출된 치근 면을 완전히 덮 을 수 있을 때까지 터널 내면을 이완시켰다. 이어서 동측 구개에서 1- $1.5 \mathrm{~mm}$ 두께로 상피하결합조직을 채득한 후 치유에 방해가 되는 지방 조직 등을 제거 하여 균일 한 두께로 다듬었다(Fig. 1D). 공여부는 지혈 한 후 봉합 하였다(Black silk 4-0). 미리 형성한 수여 부의 터널 내에 결합 조직 이식편을 넣고 근 원심 측으로 각각 단속 봉합 하여(Vicryl 6-0, ETHICON, Somerville, USA) 이식편 을 고정시켰다. 또한 이식 편을 부유 봉합을 통해 치아의 백악법랑경계에 위치시켜 고정하였다. 마지막으로 터널 의 치아 측 근 원심측 경계를 치아의 중앙을 향해 당겨 이 식편 상방으로 위치시켜 봉합하여 이식편을 피개 하였다 (Fig. 1E).

발사 시 \#31 치은이 인접치의 백악법랑경계와 동일한 수준에 위치함을 확인할 수 있었다. 또한 인접치의(\#32, 41) 치은 경계가 수술에 영향을 받지 않았으며, 치간 유
두가 술 전과 동일한 수준으로 유지되었다(Fig. 2A). 이 후 $3,6,12$ 개월 정기 검진 과정 동안 해당 부위의 증가된 치근 피개량과 각화 치은의 폭, 주위 조직과의 색조 및 형 태 조화가 안정적으로 유지 되었으며 치은 변연의 염증 또한 개선된 것을 확인 할 수 있었다(Fig. 2B, 2C). 12개월 정기 점검에서 하악 중절치 사이의 치간 유두가 퇴축된 것을 확인할 수 있는데 이는 설측에 위치된 고정성 교정 유지 장치로 인해 해당 치간부 관리가 용이하지 않아 발 생하였다(Fig. 2D). 환자는 해당 치아의 칫솔질 시 통증 을 느끼지 않았으며 치근 피개량과 색조에 있어 심미적 으로 만족하였다.

\section{증례 2}

28세 여성으로 하악 전치 치은 퇴축을 주소로 내원하 였으며, 임상 검사 상 \#41 순측에 폭 $2 \mathrm{~mm}$, 길이 $2 \mathrm{~mm}$ 의 치은 퇴축과 함께 근단 측 경계에 약 $1 \mathrm{~mm}$ 정도의 각 화 치은이 관찰되었다. 하악 전치 부의 치간 유두 퇴축이 전반적으로 관찰되었으며, 치근단 방사선 사진 상에서도 치조골 소실이 관찰되어 Miller 3급의 치은 퇴축으로 진 단하였다(Fig. $3 \mathrm{~A}, 3 \mathrm{~B}$ ). 치주 낭 깊이는 $2-3 \mathrm{~mm}$ 로 정상 이었으나, 전반적으로 하악 전치의 구강위생관리가 제대 로 이루어지지 않아 치석의 침착, 탐침 시 출혈, 치은 색 조 변화를 관찰 할 수 있었다. 치주탐침자를 치은열구내 에 넣었을 때 치은을 통해 치주탐침자가 비춰 보였으며 육안으로 치조골의 scallop이 명확하게 관찰되어 얇은 생 체형으로 진단하였다.

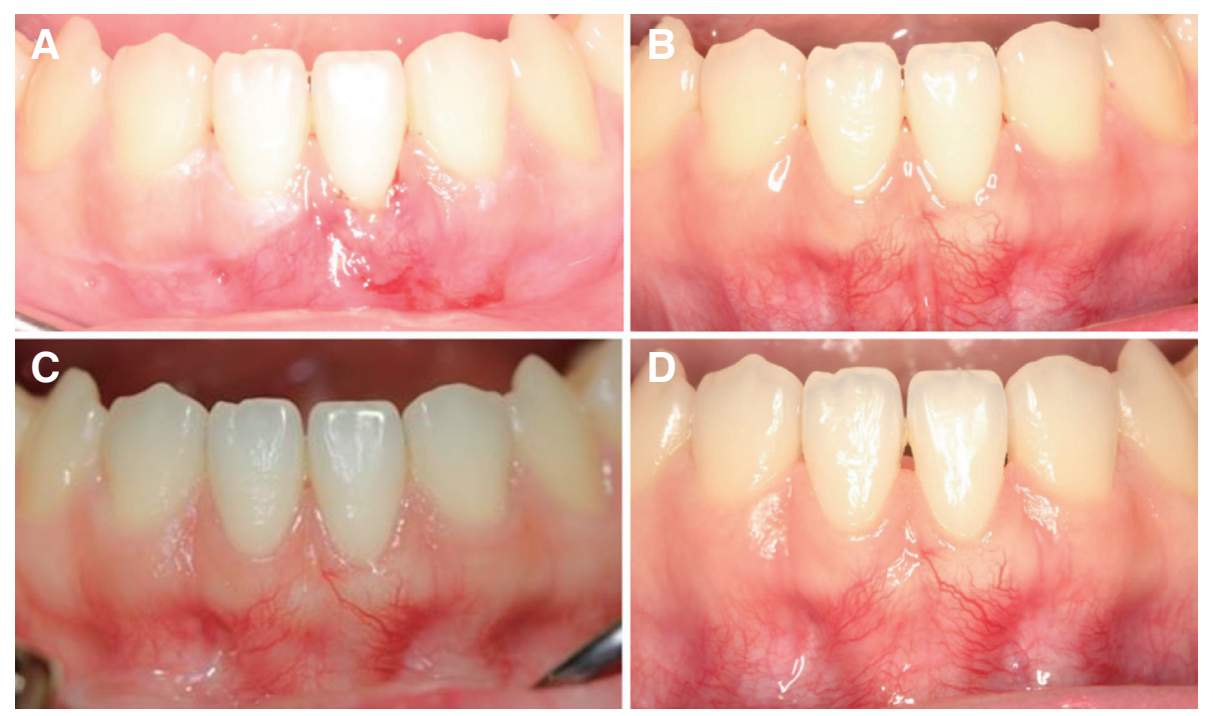

Fig. 2. Clinical view of case 1 at maintenance check. (A) Stitch-out, (B) 3 months, (C) 6 months, (D) 12 months after surgery. 
이후 술 전 처치, 상피하결합조직이식술은 증례 1과 동 일한 과정으로 진행하였다. 다만 상피하결합조직이식술 과정에서 치은 퇴축을 보이는 \#41 뿐만 아니라 \#31의 생체형 개선을 위해 수여부 터널을 \#31까지 연장하여 형 성하고 결합조직이식편을 좀 더 길게 $(15 \times 4 \mathrm{~mm})$ 채득 하여 함께 이식하였다(Fig. 3C, 3D, 3E)

발사 당시 \#41 치은 경계가 인접치의 치은과 유사한 수준에 위치함을 확인할 수 있었다(Fig 4A). 3개월 이후
정기 검진 시 해당 부위는 치근 피개량과 주위 조직과의 색조 및 형태 조화의 면에서 안정적으로 유지 되었으며 치은 변연의 염증 또한 개선된 것을 확인 할 수 있었다. 또한 \#31, 41 치은 변연이 술 전과 비교 시 좀 더 두껍게 변하였으며 각화 치은의 폭이 $1 \mathrm{~mm}$ 에서 $3 \mathrm{~mm}$ 로 증가하 였다(Fig. 4B, 4C). 환자는 구강 위생 관리를 시행하는 데 있어 불편 감을 느끼지 않았으며, 술 후 결과에 대해 심미 적으로 만족하였다.
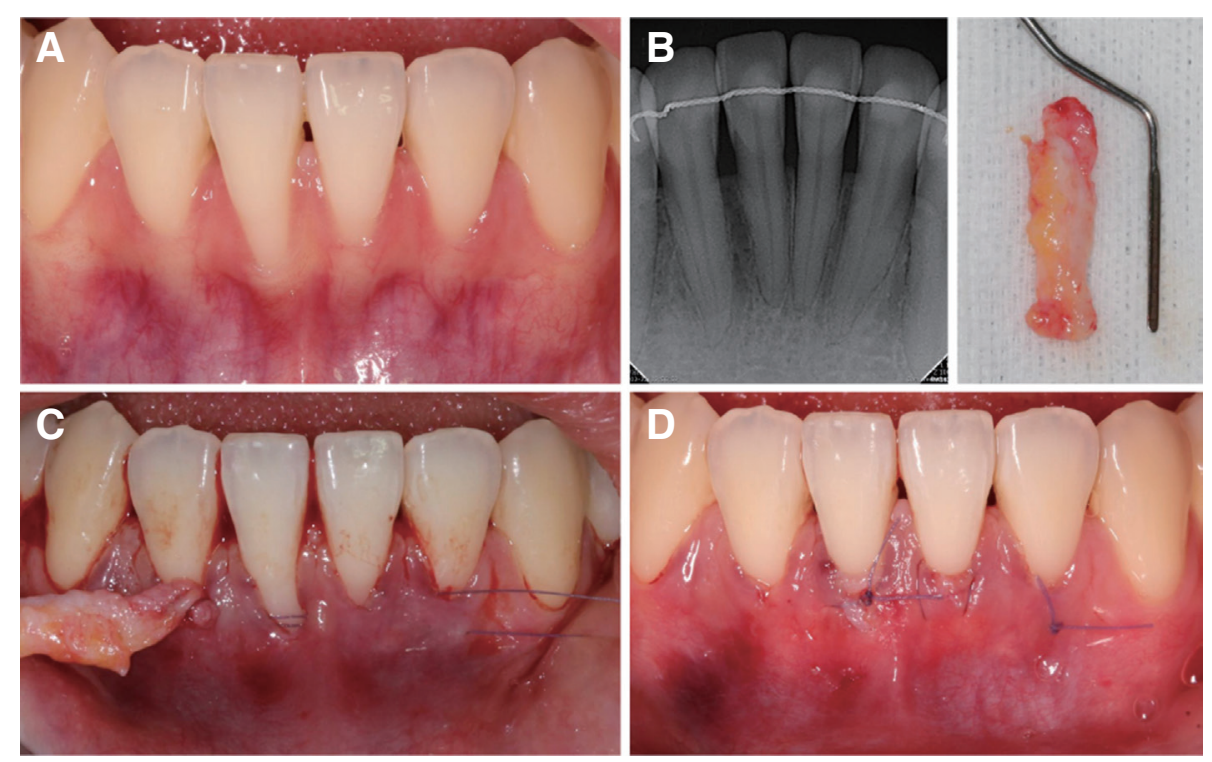

Fig. 3. Clinical photographic and radiographic view of case 2. (A) Intraoral photograph of \#41 at pre-operation, (B) Periapical radiograph, (C) Subepithelial connective tissue graft obtained from palate, (D) Graft was placed through prepared tunnel, (E) Sutured.
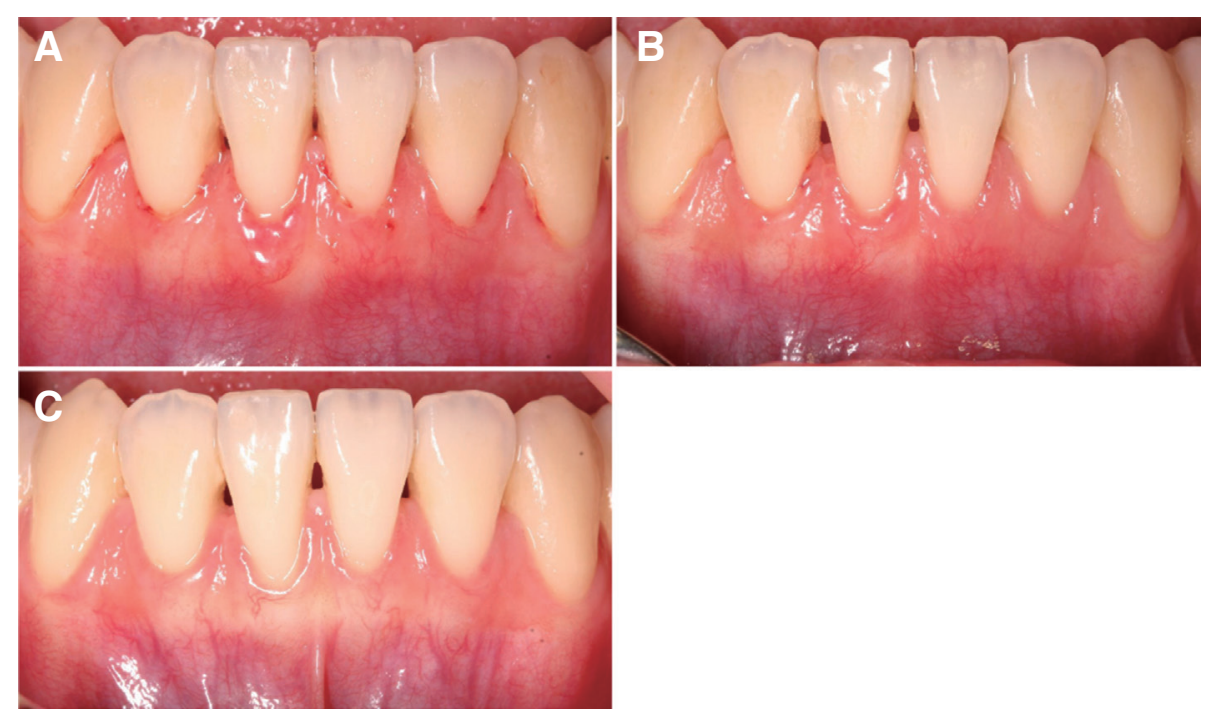

Fig. 4. Clinical view of case 2 at maintenance check. (A) Stitch-out, (B) 1 months, (C) 3 months after surgery. 


\section{고찰}

치은 퇴축은 임상에서 흔히 접할 수 있는 증상 중 하나 로, 정확한 진단과 알맞은 처치법이적용 된다면 해결 가 능한 문제이다. 진단의 과정에 있어 중요하게 고려해야 할 요소는 인접 치간부 조직의 퇴축, 치은 노출 부위 주변 의 각화 치은의 존재 유무, 그리고 치은의 두께와 관련되 는 치주 생체형을 들 수 있다. 치근 피개 술 식 이후 치은 변연의 최종 위치는 치간 유두의 높이를 통해 예상 할 수 있는 것으로 알려져 있는데, 이는 치유 기간 동안 치간부 치주 조직이 이식편 및 판막의 안정화와 혈류 공급에 중 요한 역할을 하기 때문이다. ${ }^{12}$ 즉, 치간부 치주 조직의 상 실이 있는 경우는 완전한 치근 피개를 달성할 수 없다. 본 증례보고에서 증례 1은 치간부 조직의 상실이 없었으며 증례 2는 치간부 조직 퇴축이 존재하였다. 따라서 술 후, 증례 2에서 치은 변연이 인접치와 유사한 수준에 도달하 기는 하였으나 백악법랑경계에 이르는 완벽한 치근 피개 를 이룰 수는 없었다. 본 증례 보고에서 사용되었던 LCT 를 소개한 Sculean와 Allen ${ }^{11}$ 또한 Miller class 3급에서 $60 \%$ 의 완전치근피개를 보고하였는데, 이는 종전의 $40 \%$ 에 비해서는 개선된 수치 였지만 Miller class 1, 2급에 비 해서는 낮은 예지성을 보임을 확인할 수 있다.

본 증례 보고에서 살펴 본 환자들은 모두 20대 후반의 여성으로 치주적으로 얇은 생체형이었으며 치근 피개술 을 행함에 있어 개인의 치주 생체형은 판막의 두께에 직 접적인 영향을 미치게 된다. 이식편 없이 판막의 치관 변 위 만으로 치근 피개를 이루기 위해서는 판막의 두께가 0.8 - $1.2 \mathrm{~mm}$ 정도 되어야 한다는 보고가 있었으며, ${ }^{13}$ 체 계적 문헌 고찰에 따르면 완전 치근 피개를 위한 임계 판 막 두께는 $1.1 \mathrm{~mm}$ 이상이라고 한다. ${ }^{14}$ 최근에 발표된 한 연구에 따르면, 결합조직 이식편을 치관변위판막과 함께 위치할 경우 판막의 두께와 관계없이 얇은 생체형에서 도 동일한 결과를 얻을 수 있다고 한다. ${ }^{15}$ 즉 치주 생체형 이 얇은 환자의 경우 결합 조직 이식편을 이용하는 것이 완전 치근 피개를 위해서 필수적이며, 더불어 이를 통해 치은 변연의 두께 또한 개선할 수 있는 효과를 얻을 수 있다. 증례 2에서 치은 퇴축을 보이는 \#41 뿐만 아니라 \#31에 치주 조직 생체형의 개선을 위해 결합조직 이식술 을 함께 시행하였는데, 두개 치아 모두에서 술 식 이후 육 안으로 관찰 시 치은 변연의 두께가 개선된 것을 확인 할 수 있었다.

얇은 생체형에서는 결합조직 이식 시 판막 형성법에도
주의를 기울여야 한다. 상피하결합조직이식술에 있어 가 장 널리 사용되는 방법은 치관변위판막술이며 이의 변형 으로 다양한 방법이 소개되었으며 완전 치근 피개에 있 어서도 높은 예지성을 보였다. ${ }^{16}$ 하지만 본 증례와 같이 얇은 생체형을 가진 환자의 하악 전치에 형성된 치은 퇴 축 부위는 판막이 찢어질 가능성이 높고 형성된 판막이 지나치게 얇아 괴사의 우려가 있으며 봉합의 어려움 등 의 이유로 분리형으로 판막을 형성하기 좋지 않은 환경 이다. 본 증례에 사용된 LCT은 터널링 법의 변형으로 판 막 형성 과정 중 완전한 박리와 거상이 필요 없어 혈류 공 급을 유지 할 수 있으며 조직에 가해지는 외상이 적어 환 자 불편 감을 줄일 수 있다는 장점을 가진다. 기존 터널 링 법이 주로 터널 판막을 치관측으로 이동시킨 것과 달 리 측방으로 이동시켜 봉합함으로써 구강 전정이 얕아 지거나 무리한 판막 이동으로 인해 열개가 발생할 수 있 는 문제를 개선 하였다. 다만 LCT법은 터널링을 위해 특 별히 고안된 터널링 기구가 필요하며 숙련된 전문가에 의 한 판막 형성이 필요하다. 터널링 기구는 터널 내부로 쉽 게 접근 할 수 있게 기구 마다 다양한 각도와 만곡을 가 지고 있으며, 기구의 끝이 작고 납작하며, 양날을 가지고 있다. 판막 형성 시에는 특히 터널의 범위를 충분히 넓게 이완시켜, 근 원심 측 경계를 각각 치근 중앙을 향해 측 방으로 이동 시킬 때 장력 없이 이식편을 피개 할 수 있게 해주는 것이 가장 중요하다.

두 증례 모두에서 정기 검진에서 이식 부위가 주위 조 직과 조화를 이루며 안정적으로 유지되는 것을 확인할 수 있었다. 특히 술 식 이후 1 년이 경과한 증례 1 의 경우, 발사 시와 비교해 볼 때 치은 높이의 변화가 거의 없었다. 일반적으로 술 후 연조직 수축의 대부분은 첫 한 달 째 발생하는 것으로 알려져 있으며, 이 시기 이후의 치은 위 치 및 형태는 안정적이라고 볼 수 있다. ${ }^{17}$ 두 증례 모두 설 측에 고정성 유지 장치가 있기 때문에 구강위생관리에 중점을 두어 지속적인 정기 점검을 하는 것이 필요하다.

\section{결론}

치은 퇴축을 성공적으로 해결하기 위해서는 환자의 치 간부 치주 조직의 높이 및 치주 생체형을 고려하여 이에 맞는 적절한 처치법을 선택하는 것이 가장 중요하다. 본 증례에서 사용된 LCT법은 얇은 생체형에서 효과적이었 으며, 치간부 조직이 퇴축된 경우에도 임상적으로 수용 할 만한 치료 결과를 보였다. 


\section{Acknowledgements}

본 연구는 2019년도 부산대학교치과병원 임상 연구비 지원으로 이루어 졌음

\section{ORCID}

Hyun-Joo Kim http://orcid.org/0000-0001-7553-6289

Eun-Young Kwon http://orcid.org/0000-0001-9555-0360

Ju-Youn Lee http://orcid.org/0000-0002-0772-033X

Ji-Young Joo http://orcid.org/0000-0002-4050-5797

\section{References}

1. Armitage GC. Development of a classification system for periodontal diseases and conditions. Ann Periodontol 1999;4:1-6.

2. Kassab MM, Cohen RE. The etiology and prevalence of gingival recession. J Am Dent Assoc 2003;134:2205.

3. Wennström JL. Mucogingival considerations in orthodontic treatment. Semin Orthod 1996;2:4654.

4. Merijohn GK. Management and prevention of gingival recession. Periodontol 2000 2016;71:228-42.

5. Ruf S, Hansen K, Pancherz H. Does orthodontic proclination of lower incisors in children and adolescents cause gingival recession? Am J Orthod Dentofacial Orthop 1998;114:100-6.

6. Renkema AM, Fudalej PS, Renkema A, Bronkhorst E, Katsaros C. Gingival recessions and the change of inclination of mandibular incisors during orthodontic treatment. Eur J Orthod 2013;35:249-55.

7. Frost NA, Mealey BL, Jones AA, Huynh-Ba G. Periodontal Biotype: Gingival thickness as it relates to probe visibility and buccal plate thickness. J Periodontol 2015;86:1141-9.

8. Yared KF, Zenobio EG, Pacheco W. Periodontal status of mandibular central incisors after orthodontic proclination in adults. Am J Orthod Dentofacial Orthop 2006;130:6.e1-8.

9. Melsen B, Allais D. Factors of importance for the development of dehiscences during labial movement of mandibular incisors: a retrospective study of adult orthodontic patients. Am J Orthod Dentofacial Orthop 2005;127:552-61.

10. Chambrone L, Tatakis DN. Periodontal soft tissue root coverage procedures: a systematic review from the AAP Regeneration Workshop. J Periodontol 2015;86:S8-51.

11. Sculean A, Allen EP. The laterally closed tunnel for the treatment of deep isolated mandibular recessions: surgical technique and a report of 24 cases. Int J Periodontics Restorative Dent 2018;38:479-87.

12. Zucchelli G, Mele M, Stefanini M, Mazzotti C, Mounssif I, Marzadori M, Montebugnoli L. Predetermination of root coverage. J Periodontol 2010; 81:1019-26.

13. Leong DJ, Wang HL. A decision tree for soft tissue grafting. Int J Periodontics Restorative Dent 2011;31:307-13

14. Hwang D, Wang HL. Flap thickness as a predictor of root coverage: a systematic review. J Periodontol 2006;77:1625-34.

15. Garces-McIntyre T, Carbonell JM, Vallcorba L, Santos A, Valles C, Nart J. Coronal advanced flap in combination with a connective tissue graft. Is the thickness of the flap a predictor for root coverage? A prospective clinical study. J Clin Periodontol 2017;44:933-40.

16. Sanz M, Simion M. Surgical techniques on periodontal plastic surgery and soft tissue regeneration: consensus report of Group 3 of the 10th European Workshop on Periodontology. J Clin Periodontol 2014;41 Suppl 15:S92-7.

17. Pini Prato GP, Baldi C, Nieri M, Franseschi D, Cortellini P, Clauser C, Rotundo R, Muzzi L. Coronally advanced flap: the post-surgical position of the gingival margin is an important factor for achieving complete root coverage. J Periodontal 2005;76:71322. 


\title{
얇은 치주 생체형 환자에서 교정 치료 후 발생한 하악 전치부 치은 퇴축에 대한 laterally closed tunnel procedure의 처치: 증례보고
}

\author{
김현주 ${ }^{1,2}$, 권은영 $^{3}$, 이주연 ${ }^{1,2}$, 주지영 ${ }^{1,2 *}$ \\ ${ }^{1}$ 부산대학교 치의학전문대학원 치주과학교실 \\ ${ }^{2}$ 부산대학교 치과병원 치주과 \\ ${ }^{3}$ 부산대학병원 치과진료처
}

본 증례 보고는 하악 전치에 발생한 치은 퇴축을 laterally closed tunnel technique을 이용하여 처치하였다. 환자는 모두 과거 교정 치료 시 하악 전치의 경사도를 변화시켰으며 치주 적으로 얇은 생체형을 가지고 있었다. 터널링법으로 수여 부 를 형성하고 구개 측에서 채득한 결합조직이식편을 터널내에 위치시킨 후 판막의 변연을 치근 중앙부를 향해 측방으로 이동시켜 봉합하여 이식편을 피개 하였다. 얇은 치주 생체형에도 불구하고 치근 피개를 성공적으로 얻을 수 있었으며 각 화 치은의 획득과 주변 조직과의 색, 형태 조화로 심미성을 달성할 수 있었다.

(구강회복응용과학지 2019;35(4):253-9)

주요어: 치은 수술; 치은 퇴축; 심미; 치료 결과; 판막

*교신저자: 주지영

(50612)경남 양산시 물금읍 금오로 20 부산대학교 치의학전문대학원 치주과

Tel: 055-360-5103 | Fax: 055-360-5194 | E-mail: joojy@pusan.ac. kr

접수일: 2019년 9월 23일 | 수정일: 2019년 10월 28일 | 채택일: 2019년 11월 13일 